\title{
GENETIC DIFFERENCES BETWEEN THE CHINESE AND EUROPEAN RACES OF THE COMMON CARP
}

\section{MULTI-CHARACTER VARIATION-A RESPONSE TO THE DIVERSE METHODS OF FISH CULTIVATION IN EUROPE AND CHINA}

\author{
G. WOHLFARTH \\ Fish and Aquaculture Research Station, Dor, Israel \\ and \\ ROM MOAV and G. HULATA \\ Department of Genetics, The Hebrew University of Jerusalem, Jerusalem, Israel
}

Received 20.vi.74

\section{SUMmARY}

\begin{abstract}
The European and Chinese races of the common carp and their $\mathrm{F}_{1}$ crossbreds were tested in five experimental environments. The two races differ widely and conspicuously in many characters. The Chinese carp has poorer growth rate but higher viability and fertility, earlier sexual maturity, higher resistance to crowding, better adaptation to unfavourable pond conditions, higher seine escapability, longer body and larger weight differences between females and males. The crossbreds between the two races are intermediate in some characters (differences in weight between females and males and seine escapability). In other characters (weight gain, specific adaptation to poor conditions and viability), the crossbreds showed dominance or even heterosis. An hypothesis was advanced to explain these genetic differences in terms of selection response to the different fish-farming practices that existed in the two regions. Specific suggestions were made for implementation of the present findings to genetic improvement of carp breeding stocks.
\end{abstract}

\section{INTRODUGTION}

Extensive tests were conducted on the European and the Chinese (Big-Belly) races of common carp. Moav, Hulata and Wohlfarth (1975) described the results of these tests related to growth rate and response of growth rate to the quality of the environment. In the present paper the results of three further characters, i.e. size differences between females and males, viability and seine escapability are genetically analysed, multi-character profiles, involving 13 traits, are defined; and an hypothesis is outlined explaining the differences between the European and the Chinese carp in terms of adaptive evolution to the widely different methods of fish cultivation practised in the two regions.

\section{Materials and methods}

Detailed description of the genetic stocks (table 1) and the experimental procedures were outlined in the preceding paper (Moav et al., 1975). The tested stocks included the Chinese race of carp, named Big-Belly (group 1, table 1), and three strains of the European race: Našice (group 2)-imported from Yugoslavia, where it was selected for many generations; Gold (group 3) -founded in 1963 with individuals marked by the recessive colour mutation 
Gold; and Dor-70 (group 4)-developed at Dor from a selection experiment for fast growth rate. The remaining eight groups participating in the tests were crossbreds: Three groups $(1 \times 2,1 \times 3$ and $1 \times 4$; table 1$)$ were $F_{1}$ crossbreds between the Big-Belly and the three European strains; Three groups $(2 \times 3,2 \times 4$ and $3 \times 4)$ were $\mathrm{F}_{1}$ crossbreds among the above three European strains; $\vdash$ was a commercially used $F_{1}$ crossbred between the Gold inbred and another local inbred group marked by two recessive genes Blue and Grey, and group $\mathrm{V}$ was an $\mathrm{F}_{1}$ crossbred between a group introduced to Israel from the Netherlands and an excellent local crossbred $(\mathrm{T})$.

TABLE 1

Number of fish stocked according to the 12 tested groups

\begin{tabular}{|c|c|c|c|c|c|c|c|c|}
\hline \multirow[b]{2}{*}{ Group } & & & \multicolumn{4}{|c|}{ Environments at Dor* } & \multirow[b]{2}{*}{ Yehiam } & \multirow[b]{2}{*}{ Gan-Shmuel } \\
\hline & \multicolumn{2}{|c|}{ Designations } & 1 & 2 & 3 & 4 & & \\
\hline Big-Belly & 1 & $B B$ & 132 & 100 & 80 & 52 & 190 & 307 \\
\hline$B B \times$ Nasice & $1 \times 2$ & $B B \times N a s$ & 132 & 60 & 80 & 30 & 150 & 189 \\
\hline$B B \times$ Gold & $1 \times 3$ & $B B \times G$ & 132 & 90 & 80 & 30 & 370 & 351 \\
\hline$B B \times$ Dor -70 & $1 \times 4$ & $B B \times D$ or & 132 & 110 & 81 & 43 & 408 & 420 \\
\hline Našice & 2 & Nas & 132 & 80 & 80 & 40 & - & 220 \\
\hline Našice $\times$ Gold & $2 \times 3$ & $\mathcal{N a s} \times G$ & 264 & 160 & 160 & 80 & 589 & \\
\hline Našice $\times$ Dor-70 & $2 \times 4$ & Nas $\times$ Dor & 132 & 85 & 80 & 35 & 163 & \\
\hline Gold & 3 & $G$ & 132 & 80 & 80 & 40 & 245 & \\
\hline Gold $\times$ Dor -70 & $3 \times 4$ & $G \times D o r$ & 132 & 90 & 80 & 31 & 300 & -4571 \\
\hline Dor -70 & 4 & Dor & 132 & 80 & 80 & 40 & 692 & \\
\hline$T \times$ Holland $-B$ & & $\mathrm{~V}$ & 132 & 80 & 80 & 40 & 529 & \\
\hline Gold $\times$ Blue-Grey & & $\vdash$ & 119 & 80 & 80 & 40 & 529 & \\
\hline & 1703 & 1098 & 1041 & 502 & 4165 & 5838 \\
\hline \multicolumn{3}{|c|}{ Mean/pond/group } & $35 \cdot 5$ & $22 \cdot 9$ & $21 \cdot 7$ & $10 \cdot 4$ & - & - \\
\hline \multicolumn{3}{|c|}{ Mean/pond } & 462 & 275 & 260 & 125 & - & - \\
\hline \multicolumn{3}{|c|}{ Mean/1000 m² } & 1064 & 685 & 651 & 314 & - & - \\
\hline \multicolumn{3}{|c|}{ Mean weight gain/fish (g) } & 349 & 437 & 530 & 778 & 373 & - \\
\hline
\end{tabular}

Spawning of all the 12 groups took place at the end of April. Each group was nursed in a separate pond to an average weight of 20 to $30 \mathrm{~g}$, at which stage the fish were marked by branding. The tests (initiated at the beginning of July and terminated at mid-November) were carried out in 16 experimental ponds ( $400 \mathrm{~m}^{2}$ each) at Dor, plus two large ponds (about 8 acres), one at the fish farm of Yehiam, and the second at the fish farm of GanShmuel. The 16 ponds at Dor were divided into four sets of four, each set constituting a different environmental treatment as described earlier (Moav et al., 1975).

\section{EXPERIMENTAL RESULTS}

(i) Weight differences between males and females

Kessler, Wohlfarth, Lahman and Moav (1961), Kirpichnikov (1971) and several other workers showed that female carp are larger than male carp. At the termination of the tests at Dor, when the fish were approximately 7 months old, the two sexes were weighed separately (table 2). The results show that the Big-Belly females were 40 per cent larger than their males, while in the European carp the differences were smaller, ranging between 

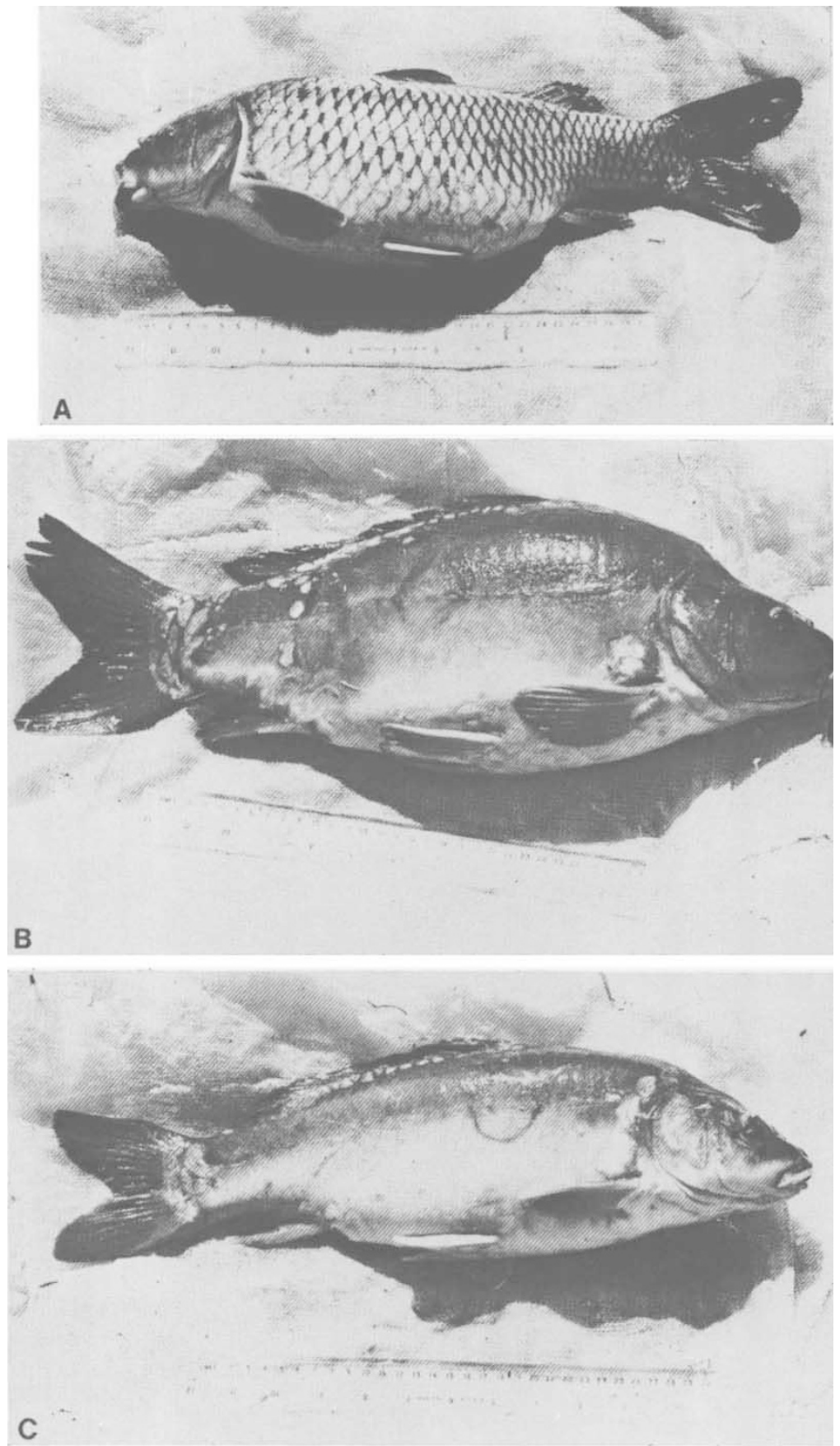

Plate I

Typical four-year-old males of the Chinese and the European races of the Common Carp. (Fig. A-the Chinese Big-Belly, fig. B-the Yugoslavian Našice and fig. C--the Israeli Dor-70.) 
9 per cent to 16 per cent, and in the inter-race crossbreds the differences were intermediate (17 per cent to 33 per cent). Note that the Error variance of the inter-sex differences was relatively high, hence small differences are not significant.

Relative potence was measured by the potence ratio, $D / A$, when: $A=$ half the difference between the parents, and $D=$ deviation of the crossbred from the mid-parental point (Bucio-Alanis et al., 1969). The potence ratios of the six crossbreds that participated in the tests together with their two parents are given in table 5, which shows that weight differences between females and males were almost completely genetically additive $(D / A \cong 0)$.

TABLE 2

Weight differences between females and males

(The differences are expressed as percentages of the males' weights, i.e. $100 \times$ (Female-Male)/(Male))

Environments at Dor

\begin{tabular}{|c|c|c|c|c|c|c|}
\hline \multirow[b]{2}{*}{ Group } & & \multicolumn{2}{|r|}{ Mean } \\
\hline & $\begin{array}{c}1 \\
\%\end{array}$ & $\begin{array}{r}2 \\
\%\end{array}$ & $\begin{array}{c}3 \\
\%\end{array}$ & $\begin{array}{l}4 \\
\%\end{array}$ & $\begin{array}{c}\text { Mean* } \\
\%\end{array}$ & $\begin{array}{l}\text { wt. gain } \\
\mathrm{g}\end{array}$ \\
\hline Big-belly & 47 & 23 & 44 & 44 & 40 & 336 \\
\hline 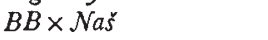 & 18 & 68 & 29 & 13 & 33 & 491 \\
\hline$B B \times G$ & 23 & 12 & 32 & 21 & 23 & 470 \\
\hline$B B \times$ Dor-70 & 9 & 29 & 19 & 3 & 17 & 500 \\
\hline Našice & 15 & 10 & 10 & 12 & 13 & 439 \\
\hline Nas $\times$ Gold & 16 & 6 & 23 & 18 & 15 & 559 \\
\hline Nas $\times$ Dor-70 & 20 & 4 & 12 & 4 & 14 & 558 \\
\hline Gold & 8 & 15 & 9 & 6 & 10 & 443 \\
\hline$G \times D o r-70$ & 8 & 14 & 15 & 14 & 11 & 516 \\
\hline Dor-70 & 15 & 19 & 14 & 23 & 16 & 556 \\
\hline$T \times$ Holland $-B(\mathrm{~V})$ & 12 & 16 & 21 & 20 & 15 & 539 \\
\hline Gold $\times$ Blue-Grey $(\vdash)$ & 10 & 7 & 9 & 8 & 9 & 514 \\
\hline Mean & $16 \cdot 8$ & $18 \cdot 6$ & $19 \cdot 8$ & $15 \cdot 5$ & $18 \cdot 0$ & 494 \\
\hline
\end{tabular}

* The mean was computed by adding: twice Environment-1, plus Environment-2 plus Environment-3 and dividing this by 4 , i.e. mean $=(2($ Env-1 $)+($ Env-2) $+($ Env-3) $) / 4$. Environment- 4 was excluded because the small numbers of fish made the results in this "Environment" very unreliable.

\section{(ii) Viability}

The percentages of missing fish of each group at each one of the four environments at Dor and the two ponds at Yehiam and Gan-Shmuel are listed in table 3. The pond at Yehiam was not emptied completely on termination of the test, therefore, only some of the missing fish were due to mortality, the remaining being those that were left in the pond, i.e. those that were not caught by the seining nets. Since seine escapability has a wide genetic variability in carp (see next section and table 4 ), mortality estimates cannot be extracted from the results of this pond.

The pond at Gan-Shmuel suffered mass mortality due to an unidentified cause. The pond was restocked with a large number of fry of a commercial cross of local carp without changing the water. At the end of the growing season the pond was completely emptied, the surviving carp were found to be, exclusively, Big-Belly and its three crossbreds with the European carp. 
All European carp of the original, as well as the second stocking had died. The four surviving groups differed from the European carp in that they had the wild-type (dominant) full scale cover, as contrasted with the limited cover of scales of the European carp (the Mirror recessive pattern). The fact that the Big-Belly at Gan-Shmuel had a mortality of 44 per cent as compared to about 75 per cent mortality of its three crossbreds shows that the Big-Belly possessed a high resistance to mortality, unrelated to its full scale cover.

TABLE 3

Percentages of missing fish of the 12 tested groups

\begin{tabular}{|c|c|c|c|c|c|c|}
\hline Group & $\begin{array}{c}1 \\
\%\end{array}$ & $\begin{array}{c}2 \\
\%\end{array}$ & $\begin{array}{c}3 \\
\%\end{array}$ & $\begin{array}{l}4 \\
\%\end{array}$ & $\begin{array}{c}\text { Yehiam } \\
\%\end{array}$ & $\begin{array}{c}\text { Gan- } \\
\text { Shmuel } \\
\%\end{array}$ \\
\hline Big-Belly & 4.5 & $6 \cdot 0$ & $1 \cdot 3$ & $3 \cdot 8$ & $30 \cdot 5$ & $44 \cdot 0$ \\
\hline$B \vec{B} \times \mathcal{N} a s^{y}$ & $12 \cdot 1$ & $8 \cdot 3$ & $7 \cdot 5$ & $10 \cdot 0$ & $17 \cdot 3$ & $74 \cdot 1$ \\
\hline$B B \times G$ & $10 \cdot 6$ & 8.9 & $5 \cdot 0$ & $0 \cdot 0$ & $20 \cdot 8$ & $71 \cdot 2$ \\
\hline$B B \times$ Dor -70 & $9 \cdot 1$ & $6 \cdot 4$ & $1 \cdot 2$ & $2 \cdot 3$ & $19 \cdot 9$ & 79.8 \\
\hline Našice & $19 \cdot 7$ & $21 \cdot 3$ & $18 \cdot 7$ & $12 \cdot 5$ & - & \\
\hline Nas $\times$ Gold & $13 \cdot 3$ & $6 \cdot 3$ & $12 \cdot 5$ & $5 \cdot 0$ & $20 \cdot 4$ & \\
\hline Nas $\times$ Dor -70 & $13 \cdot 6$ & $10 \cdot 6$ & $15 \cdot 0$ & $14 \cdot 3$ & 31.9 & \\
\hline Gold & $32 \cdot 6$ & $13 \cdot 7$ & $23 \cdot 7$ & $20 \cdot 0$ & $29 \cdot 8$ & \\
\hline$G \times$ Dor-70 & $13 \cdot 6$ & 8.9 & $8 \cdot 7$ & $6 \cdot 5$ & $29 \cdot 3$ & 100 \\
\hline Dor-70 & $20 \cdot 5$ & $8 \cdot 7$ & $6 \cdot 3$ & $12 \cdot 5$ & $25 \cdot 1$ & \\
\hline$T \times$ Holland-B $(\mathrm{V})$ & $14 \cdot 4$ & $13 \cdot 3$ & $13 \cdot 7$ & $14 \cdot 6$ & $28 \cdot 7$ & \\
\hline Gold $\times$ Blue-Grey $(\vdash)$ & $19 \cdot 3$ & $11 \cdot 3$ & 17.5 & $12 \cdot 5$ & $27 \cdot 6$ & \\
\hline Means & $15 \cdot 1$ & $9 \cdot 8$ & $11 \cdot 1$ & $9 \cdot 2$ & $25 \cdot 1$ & - \\
\hline
\end{tabular}

The average mortality rate in the 16 ponds at Dor was within the range of similar commercial fattening ponds. Here the Big-Belly showed an excellent viability (only 4 per cent mortality) and its crossbreds had intermediate mortalities (about 7 per cent). The Gold European inbred suffered the highest mortality rate $(22.5$ per cent $)$. This high value was partially due to predators that easily spot the Gold carp by its conspicuous colour. The second-highest mortality rate was that of the Našice European inbred (18 per cent). The high mortality of this group is probably an expression of inbreeding depression. The mortality of the crossbreds among the European carp ranged between 9 per cent to 15 per cent, and Dor-70 also fell within this range (12 per cent). Table 5 shows that in all the six crosses, lower mortality was dominant over higher mortality. Most striking is the cross between the two inbreds $\mathcal{N a s i c e}$ and Gold which shows a very high degree of heterosis.

Seine escapability. Moav and Wohlfarth (1970) have demonstrated the existence of genetic variation in the ability of carp to escape seines. The biweekly weighing of seined samples of fish at Dor provided an opportunity for measuring differences in seine escapability between the 12 tested groups (table 4). The Big-Belly were found to have an outstandingly high capability of escaping seining nets. On the average, only 1.5 per cent of the Big-Belly individuals present in the ponds were caught on any given date. The highest rate of catchability was that of the Gold inbred (36 per cent). The other European groups fell within the range of 16 per cent to 25 per cent. The 
crossbreds between the Big-Belly and the Europeans had an average of 8 per cent caught fish, showing a slight average dominance for the high escapability of the Big-Belly (table 5).

\section{Discussion}

Known genetic differences between the Chinese Big-Belly and the European domesticated carp in 13 characters are summarised in table 6 .

TABLE 4

Percentages of fish caught by seining at Dor on six dates

(The percentages on the first three dates were computed from the mean of the numbers stocked and recovered, and those of the last three dates from the numbers recovered)

\begin{tabular}{|c|c|c|c|c|c|c|c|c|c|}
\hline \multirow[b]{2}{*}{ Group } & \multicolumn{7}{|c|}{ Date of seining } & \multicolumn{2}{|c|}{ No. of fish } \\
\hline & $\begin{array}{c}28.7 \\
\%\end{array}$ & $\begin{array}{c}12.8 \\
\%\end{array}$ & $\begin{array}{c}26.8 \\
\%\end{array}$ & $\begin{array}{l}8.9 \\
\%\end{array}$ & $\begin{array}{c}30.9 \\
\%\end{array}$ & $\begin{array}{c}13.10 \\
\%\end{array}$ & $\begin{array}{c}\text { Mean } \\
\%\end{array}$ & Stocked & Recovered \\
\hline Big-Belly & $1 \cdot 1$ & $0 \cdot 3$ & $1 \cdot 7$ & $1 \cdot 1$ & $1 \cdot 4$ & $3 \cdot 4$ & $1 \cdot 5$ & 357 & 349 \\
\hline$B B \times \mathcal{N a s}$ & $13 \cdot 2$ & $5 \cdot 6$ & $7 \cdot 7$ & $5 \cdot 1$ & $8 \cdot 1$ & $12 \cdot 1$ & $8 \cdot 6$ & 287 & 272 \\
\hline$B B \times G$ & $4 \cdot 7$ & $4 \cdot 4$ & $6 \cdot 7$ & $5 \cdot 6$ & $7 \cdot 8$ & $15 \cdot 7$ & $7 \cdot 4$ & 319 & 306 \\
\hline$B B \times$ Dor & $9 \cdot 9$ & $3 \cdot 9$ & $5 \cdot 9$ & $3 \cdot 8$ & $10 \cdot 1$ & $8 \cdot 4$ & $7 \cdot 0$ & 355 & 345 \\
\hline$B B \times$ Europeans* & $9 \cdot 2$ & $4 \cdot 6$ & $6 \cdot 8$ & $4 \cdot 8$ & $8 \cdot 7$ & $11 \cdot 9$ & $7 \cdot 7$ & 961 & 923 \\
\hline Našice & $30 \cdot 9$ & $15 \cdot 3$ & $20 \cdot 6$ & $22 \cdot 7$ & $24 \cdot 9$ & $31 \cdot 6$ & $24 \cdot 3$ & 301 & 269 \\
\hline $\mathcal{N} a s \times G$ & $26 \cdot 1$ & $18 \cdot 8$ & $26 \cdot 2$ & $19 \cdot 3$ & $29 \cdot 2$ & $31 \cdot 8$ & $23 \cdot 6$ & 629 & 595 \\
\hline Nas $\times$ Dor & $23 \cdot 2$ & $12 \cdot 3$ & $19 \cdot 0$ & $17 \cdot 7$ & $24 \cdot 0$ & $28 \cdot 1$ & $19 \cdot 1$ & 310 & 288 \\
\hline Gold & $44 \cdot 0$ & $27 \cdot 8$ & $32 \cdot 6$ & $27 \cdot 5$ & $39 \cdot 8$ & $43 \cdot 4$ & $35 \cdot 9$ & 291 & 251 \\
\hline$G \times D o r$ & $24 \cdot 4$ & $12 \cdot 1$ & $21 \cdot 6$ & $18 \cdot 5$ & $26 \cdot 5$ & $25 \cdot 5$ & $21 \cdot 4$ & 315 & 298 \\
\hline Dor -70 & $25 \cdot 8$ & $9 \cdot 7$ & $15 \cdot 5$ & $11 \cdot 5$ & $14 \cdot 6$ & $24 \cdot 3$ & $16 \cdot 9$ & 310 & 288 \\
\hline $\mathrm{V}$ & $29 \cdot 1$ & $14 \cdot 1$ & $17 \cdot 9$ & $11 \cdot 4$ & $23 \cdot 2$ & $24 \cdot 9$ & $18 \cdot 4$ & 313 & 289 \\
\hline$G \times$ Blue-Grey $(1-)$ & $31 \cdot 4$ & $13 \cdot 0$ & $18 \cdot 8$ & $14 \cdot 9$ & $27 \cdot 2$ & $29 \cdot 5$ & $22 \cdot 5$ & 293 & 268 \\
\hline Mean & $21 \cdot 8$ & $11 \cdot 7$ & $16 \cdot 6$ & $13 \cdot 2$ & $19 \cdot 8$ & $23 \cdot 1$ & $17 \cdot 7$ & 4081 & 3818 \\
\hline
\end{tabular}

* Means of the three groups $B B \times \mathcal{N a s}, B B \times G$, and $B B \times$ Dor.

\section{TABLE 5}

Potence ratios of three quantitative traits measured on the six crossbreds of the half-diallele matings

\begin{tabular}{|c|c|c|c|c|c|c|}
\hline \multirow[b]{2}{*}{$\begin{array}{l}\text { Crossbred } \\
\text { group }\end{array}$} & \multicolumn{2}{|c|}{$\begin{array}{c}\left(q-{ }^{*}\right) \text { wt. gain } \\
\text { difference }\end{array}$} & \multicolumn{2}{|c|}{ Mortality } & \multicolumn{2}{|c|}{$\begin{array}{l}\text { Seine escapability } \\
(\%)\end{array}$} \\
\hline & $\begin{array}{l}A \\
\mathrm{~g}\end{array}$ & $D / A$ & $\begin{array}{l}A \\
\%\end{array}$ & $D / A$ & $\begin{array}{l}A \\
\%\end{array}$ & $D / A$ \\
\hline$B B \times \mathcal{N} a s$ & 13.5 & 0.48 & $7 \cdot 1$ & $-0 \cdot 21$ & $11 \cdot 4$ & -0.38 \\
\hline$B B \times G$ & $15 \cdot 0$ & $-0 \cdot 13$ & $9 \cdot 3$ & $-0 \cdot 76$ & $17 \cdot 2$ & -0.66 \\
\hline$B B \times$ Dor & $17 \cdot 0$ & -0.35 & $4 \cdot 1$ & -0.78 & $7 \cdot 7$ & -0.29 \\
\hline $\mathcal{N} a s \times G$ & 1.5 & $2 \cdot 33$ & $2 \cdot 2$ & $-5 \cdot 0$ & $5 \cdot 8$ & $-1 \cdot 12$ \\
\hline Nas $\times$ Dor & $1 \cdot 5$ & -0.33 & $3 \cdot 1$ & -0.54 & $3 \cdot 7$ & -0.41 \\
\hline$G \times$ Dor & $3 \cdot 0$ & -0.67 & $5 \cdot 3$ & $-1 \cdot 5$ & $9 \cdot 5$ & -0.53 \\
\hline Mean & $8 \cdot 6$ & -0.01 & $5 \cdot 2$ & -1.04 & $9 \cdot 2$ & -0.55 \\
\hline
\end{tabular}

These include: (1) The three characters analysed in the present paper (weight differences between females and males, viability and seine escapability). (2) The three component characters of growth rate analysed in the preceding paper (Moav et al., 1975): post-juvenile average growth rate over the range of environments of the present experiment, tolerance to poor pond 
condition due to crowding and rate of response to improved environment. (3) Six quantitative characters that were not analysed in the present experiment: juvenile growth rate, egg size, relative body length, abundance of gamete production, onset of sexual maturity, and overall fertility (a complex trait determined by the last two characters along with other components of reproductivity such as frequency and ease of spawning, egg hatchability and fry survival). (4) The Big-Belly as well as all other wild races of the common carp have a full scale cover, while the domesticated European carp has only a limited number of large scales with most of the body being uncovered by scales (Wohlfarth et al., 1963; Shpet, 1966).

\section{TABLE 6}

Genetic variation, potence direction and presumed selection differences between the European and the Chinese carp

(The presumed selection intensity and direction of each character in Europe and in China are indicated by the number of pluses and minuses. The pluses indicate the direction implied in the left-hand column of the table.)

Character

Growth rate

1. Juvenile (first 3 months after hatching)

2. Post-juvenile: average over a wide range of environments

3. Tolerance to poor environment

4. Responsiveness to environmental inputs

5. Weight difference: female minus male

6. Egg size

7. Seine escapability

8. Viability

9. Body shape: height/length

10. Scale cover

11. Gonad weight/body weight

12. Onset of sexual maturity

13. Overall fertility

$\overbrace{\text { European }}^{\text {Relative magnitude }} \underbrace{\text { Potence }}_{\text {Chinese }} \begin{gathered}\text { ratio* } \\ \text { Ching }\end{gathered}$

low
high
low
high
small
small
low
low
high
minimal
low
late
low

high
low
high
low
big
big
high
high
low
full
high
early
high

-
$D_{E} / A>1$
$D_{C} / A>1$
$D_{C} / A<-1$
$D / A \simeq 0$
$D_{C} / A \simeq 0.5$
$D_{C} / A>1$
$D_{\mid A} \simeq 0$
$D_{C} / A=1$
-
-

Selection intensity

$\overbrace{\text { European }}^{\text {Chinese }}$

* Relative degree and direction of potence were measured by the ratio $D / A$ (see text). $D_{C}$ and $D_{E}$ indicate, respectively, potence in the direction of the Chinese and the European carp.

The between-race differences for all the above characters, their heterosis magnitude (when known) and direction, as summarised in table 6, show a multi-character profile of genetic differences between the two races. Consideration of the profile differences enables an insight into the evolutionary adaptation of each race to its specific environment as defined by the widely diverse methods of fish culture in the two regions. It also enables a better evaluation of the breeding potentialities of the two races and their hybrids.

The most prominent features of the profile differences may be summarised as follows:

(i) Within the present experimental range of environments the domesticated European carp has a considerably faster post-juvenile average growth rate than the Big-Belly, with faster growth rate showing heterosis over slower 
growth rate. This is contrasted with the relatively faster juvenile growth rate of the Big-Belly (Hulata et al., 1974).

(ii) Growth rate of the Big-Belly was less depressed by poor pond condition than that of the European carp. Heterosis was in the direction of higher tolerance to poor environment.

(iii) The European carp showed a considerably higher responsiveness to improved pond conditions than the Big-Belly. The overall rate of response is not subject to directional non-additive genetic effects (Moav et al., 1975).

(iv) Weight differences between females and males was 40 per cent in the Big-Belly and 15 per cent in the European carp with intermediate interrace crossbreds.

(v) The Big-Belly showed a higher ability to escape seining nets and its crossbreds with the European carp were intermediate in this respect.

(vi) Viability of the Big-Belly was considerably higher than that of the European carp in all the environments, the difference being more pronounced in crowded ponds and heterosis being in the direction of higher viability.

(vii) The body of the Big-Belly is longer than that of the European carp, and it is protected by a full cover of scales.

(viii) The Big-Belly reaches sexual maturity earlier than the European carp, it has bigger eggs, and a much higher ratio of gonad to body weight (Hulata, Moav and Wohlfarth, 1974). In general, overall fertility and reproductivity are much higher in the Big-Belly.

Thus, it appears that the Big-Belly excels in all aspects of reproduction and viability, particularly under harsh conditions, while the European carp is more capable of taking advantage of favourable pond conditions by growing faster, reaching higher weights and yields when appropriate external inputs are available.

Carp farming in Europe and China. The above wide multi-character variation between the European and the Chinese races of carp may be explained in terms of their respective adaptive evolution in the diverse carp farming practices. The major features distinguishing the two environments to which the two races were exposed for many generations may be outlined as follows (Mann, 1961):

In Europe, spawning is performed in the spring in special small ponds filled with clean water. From the spawning ponds the hatched fry are transferred to nursery ponds where they grow hroughout the first year of their life at densities of 4000 to 12,000 per acre, and reach average weights below $100 \mathrm{~g}$. Typical European fattening ponds of carp are filled with well or river water in the spring and stocked with a counted number of 1-year-old fingerlings at relatively low densities (400 to 1000 per acre). During the summer (the growing season in Europe) little harvesting is done. The fish are fed several times a week and the ponds are manured once or twice a year. Care is taken to minimise losses due to diseases, parasites and predators. At the end of the summer the ponds are completely emptied, and all the fish are harvested and sent to the market. Often 2 years of growth in the fattening ponds are needed to reach the required market weight of over $1 \mathrm{~kg}$. The largest individuals with the highest ratio of height over length (the tallest) are selected as breeding stocks. These spawn when they are 3 or 4 years old, and are kept as breeders for several years.

Fish farming in China was to a large extent a part of subsistence farming. 
Carp reproduced and grew in the same crowded ponds where they co-existed with the four or five other fish species, which together make the classical Chinese polyculture fish farming (Hoffman, 1934; Drews, 1961 ; Tang, 1970; Bardach et al., 1972). This is contrasted with the predominantly monoculture of the common carp in Europe. Many of the Chinese ponds could not be drained easily so that harvesting was done by seining whenever fish were needed for home consumption or for marketing. Hoffman (1934) wrote: "We have seen that fish are harvested every day of the year in Loh Kong Tung and they are caught by means of a large seine. ... If rain is depended upon for the water supply the fish are caught with nets and the ponds are not drained." Thus, only fish that were not caught by the repeated seining were able to reproduce. Also, spawners were caught regularly from wild stocks in the rivers, and spawning took place in corners of big ponds, enclosed by nets. To quote, again, from Hoffman (1934) ". . . females 15 inches long are placed in a pond and fenced off by net. The age does not matter so long as they are about 12 to 15 inches long. . . . With 20 or 30 of these females 20 catties [a Chinese measure of weight] of males 5 to 6 inches long, are placed". This observation supports Lin's conclusion (personal communication) that the Chinese did not practise any selective breeding of carp. The fish were fed by the cheapest fodders available such as rice bran or refuse and the ponds were heavily fertilised by human and livestock manure serving partially as direct food and partially to enrich the natural productivity of the pond. Competition in the ponds must have been very strong due to the high density, the presence of several fish species and the wide ranges of sizes and ages. The hatched fry had to compete with larger fish and were subjected to parasites, diseases and predators much more than the European fry that were hatched into special spawning ponds filled with clean water.

The evolution of the diversity between the domesticated European and Chinese carp. The very diverse environments to which the cultivated carp was exposed in China and Europe resulted in selection pressures differing in both direction and magnitude. Consequently, different types of carp have evolved. The two columns on the right side of table 6 show, for each one of 13 characters, the presumed direction and intensity of selection in the two regions. Fast growth rate (characters 1 and 2, table 6) appears to be highly favoured by natural selection for the following major reasons: (i) During the first few weeks after hatching, mortality of fish fry is very high because they are highly susceptible to diseases and parasites and are limited to food of very small particle size. Individuals that escape this critical stage, by fast early growth (character 1) gain a considerable advantage especially in China. Another selective advantage of fast growth rate is due to the high correlation between fertility (measured as number of gametes) and body weight in fish. (iii) European breeders regularly selected the largest fish for breeding, a practice which gave fast growth rate a further advantage in Europe but not in China.

The disadvantages of large body weight and hence fast growth rate, are the following: (i) Larger fish are more susceptible to low oxygen concentration in the water. This factor is relatively more important under high (China) than low (Europe) density. (ii) In China, where harvesting was done primarily by seining, smaller fish could escape the nets more easily than larger ones. This made fish size over a certain critical value highly unadaptive in China but not in Europe. 
In view of the above considerations it appears that the best evolutionary solution that optimally balances the advantages and disadvantages of fast growth rate in China would be a fast growth rate during early life, but maintenance of a relatively small adult body size. In Europe, on the other hand, the selection pressure for early (juvenile) fast growth rate is lower than that in China, but factors disfavouring post-juvenile fast growth rate are relatively unimportant. This explains why in the European carp early growth rate is slower, but later growth rate (character 2) and adult size are much higher.

Specific adaptation of growth rate of the Chinese carp to poor pond conditions and of the European carp to favourable pond conditions (characters 3 and 4) are obvious in terms of the different pond conditions to which the two races were exposed. The marked difference in the quality of the two environments also explains the observed differences in viability (character 8), scale cover (character 10) and the several reproductivity characters (characters 6, 11, 12 and 13). Natural selection strongly favours full scale cover, and Shpet (1966) demonstrated that scale reduction in the carp is associated with domestication, i.e. higher protection from physical damage and artificial selection.

The large size of the female over the male carp (character 5) may be due to a difference between the sexes in the balance of their selective forces, those favouring and disfavouring large body weight. Larger females tend to have larger eggs that enhance fry viability (Svärdson, 1949; Bagenal, 1969). This may put an extra selective force in favour of faster growth rate in females but not in males, and it is probably stronger in the Big-Belly female that has to maintain higher levels of fertility and fry viability. Another reason for the larger inter-sex difference in the Big-Belly is the preference by the Chinese farmers for large female and small male spawners (Hoffman, 1934).

Harvesting by seining in China as contrasted with pond drainage in Europe accounts for the high ability of the Big-Belly to escape seining nets (character 7) and their relatively long body (character 9) which is the best shape for passing maximum body weight through the seine's holes. Selection of high fish by the European breeders, as described earlier, would work in the opposite direction, to create the relatively high and roundish European carp.

Applications to genetic improvement of carp breeding stocks. The common stocking density of carp in Israel has been 1000 per acre. Recently, however, there is a trend for increasing the stocking rates to double or triple the above figure. This trend is associated with more intensive feeding using feeds with high protein contents. The present results indicate that under these increased stocking densities, especially when accompanied by co-stocking with relatively large numbers of fish of other species (i.e. Tilapia, Silver carp and Mullet) the Big-Belly has valuable genes for improved viability and overall specific adaptation to the harsher conditions of the crowded ponds. Indeed, under conditions of high density two crossbreds of the Big-Belly with the European carp performed at about the same level as the best Israeli (European) crossbreds. It is likely that further increase in density of carp and of supplementary fish species will further increase the relative advantage of selected hybrids between the European and the Chinese carp. 


\section{REFERENCES}

BAGEnal, T. B. 1969. Relationship between egg size and fry survival in brown trout Salmo salar L. 7. Fish Biol., 1, 349-353.

BARDACH, J. E., RYTHER, J. H., AND MCLARNEY, w. o. 1972. Aquaculture. The Farming and Husbandry of Freshwater and Marine Organisms, 868 pp. J. Wiley, N.Y.

BUCIO-ALANIS, L., PERKINS, JEAN M., AND JINKS, J. L. 1969. Environmental and genotypeenvironmental components of variability. V. Segregating generations. Heredity, 24, 115-127.

DREWs, R. A. 1961. Raising fish for food in Southeast Asia. In: Fish as Food, Vol. I (ed. G. Borgstrom), pp. 121-143. Academic Press, N.Y.

hoffman, w. E. 1934. Preliminary notes on the fresh-water fish industry of South China, especially Kwangtung province, 70 pp. Lingnan University Science Bulletin No. 5, Lingnan Univ., Canton, China.

hUlata, G., moAv, R., AND wohlfarth, G. 1974. The relationship of gonad and egg size to weight and age in the European and Chinese races of the common carp (Cyprinus carpio L.). 7. Fish Biol., 6, 745-758.

KESSler, s., WOHLfarth, G., LAHMAN, M., AND mOAv, R. 1961. Monosex culture of carp. Bamidgeh, 13, 57-60.

KIRPIGHNIKOv, v. 1971. Genetics of the common carp and other edible fish. Seminar/Study Tour of the USSR on genetic selection and hybridization of cultivated fishes. Rep. FAO/UNDP(TA), (2926), 186-201.

MANN, H. 1961. Fish cultivation in Europe. In: Fish as Food, Vol. I (ed. G. Borgstrom), pp. 77-102. Academic Press, N.Y.

MOAv, R., hulata, G., AND WOHLfarth, G. 1975. Genetic differences between the Chinese and European races of the common carp. I. Analysis of genotype-environment interactions for growth rate. Heredity, 34, 323-340.

MOAV, R., AND WOHLFARTH, G. 1970. Genetic correlation between seine escapability and growth capacity in carp. F. Hered., 61, 153-157.

SHPET, G. I. 1966. Evolution of scale cover in cultivated carp. In: Selective Breeding of Carp and Intensification of Fish Breeding in Ponds (ed. V. S. Kirpichnikov). Bull. State Sci. Res. Inst. of Lake and River Fisheries, Leningrad, 61, 97-105. (English translation, 1970. U.S.D.C., Clearing house for Federal Scientific and Technical Information, Springfield, Va. 22151).

SVÄRDSON, G. 1949. Natural selection and egg number in fish. Rep. Inst. Freshwat. Res. Drottningholm., 29, 115-122.

TANG, Y. A. 1970. Evaluation of balance between fishes and available fish foods in multispecies fish culture ponds in Taiwan. Trans. Am. Fish. Soc., 99, 708-718.

WOHLfarth, G., LAHMAN, M., AND MOAV, R. 1963. Genetic improvement of carp. IV. Leather and line carp in fish ponds in Israel. Bamidgeh, 15, 3-8. 